\title{
Textual Subjects in Motion: Letters, Literature and Print- Media in an Indian-South African Exchange (1928-1946) ${ }^{1}$
}

\author{
Meg Samuelson, Stellenbosch University
}

It is nearly a month since I left India. I wonder if the continuity of our correspondence has been broken. I hope not. I do not want to lose the prize if an enterprising 'Daily Mail' starts a prize for the longest continuous correspondence between two persons other than of a business nature. Why not you suggest the idea to some South African paper. That beats cross word puzzles and chess!

P. Kodanda Rao to M. K. Jeffreys, 14 May $1931^{2}$

\section{Introduction}

An intriguing epistolary exchange, criss-crossing the Indian Ocean and animated by the circulation of print media and literary texts, unfolded between South Africa and India from 1928 to 1946. The three figures engaged in this 'continuous correspondence' are Marie Kathleen Jeffreys (1896-1968), V. S. Srinivasa Sastri (1869-1946) and P. Kodanda Rao (c.1889-?). Jeffreys, a white South African, was employed at the Cape Town Archives; her interlocutors, Sastri and his personal secretary Rao, were based in South Africa from mid 1927 to early 1929 during Sastri’s tenure as the first Agent of Colonial India. Materialised through a network of letters and the exchange of literature and print media, the relationship between the three knits together the geographically

\footnotetext{
${ }^{1}$ Some of the material in this article has been drawn on in a forthcoming book chapter titled 'Textual Circuits and Intimate Relations: A Community of Letters across the Indian Ocean.' I am grateful to the organizers of the 'Intercolonial Networks, Oceanic Circulations: Re-Thinking the Indian Ocean' conference at the University of Technology, Sydney, March 2009, where an early and abridged version of this article was presented, as well as to the anonymous journal readers for their suggestions. I wish to thank also the National Research Foundation of South Africa and the Research Division of Stellenbosch University for funding the research on which this article is based. Finally, my thanks to the archives from which this material is drawn: the Western Cape Archives and Records Service, Cape Town; the Nehru Memorial Museum and Library, New Delhi; and the National Library, Kolkata.

${ }^{2}$ Letters from P. Kodanda Rao to M.K. Jeffreys, Jeffreys Collection, A1657: vol. 2, Western Cape Archives and Records Service. All further quotations from letters by Rao are from this source.
}

PORTAL Journal of Multidisciplinary International Studies, vol. 9, no. 1, January 2012.

Indian Ocean Traffic Special Issue, guest edited by Lola Sharon Davidson and Stephen Muecke.

ISSN: 1449-2490; http://epress.lib.uts.edu.au/ojs/index.php/portal

PORTAL is published under the auspices of UTSePress, Sydney, Australia. 
distinct domains of South Africa and India in striking ways. The geographical reach of this trans-oceanic exchange forms part of a larger web of relations and textual circulations increasingly drawing scholarly attention.

A recent turn in (post)colonial studies has shifted from tracing discursive and print flows between 'centre' and 'periphery' or along a North-South axis toward engaging South-South connections (see Boehmer 2002; Frost 2002; Hofmeyr 2008; Metcalf 2007). Thomas Metcalf, for instance, argues that 'For much of South Africa ... the ties of empire ran not only to London but also to Calcutta, Bombay and Madras’ (2007: 1). Moving away 'from the old notion of each colony dangling separately at the end of its own string,' Metcalf instead looks 'horizontally, from one colony to another, not vertically, along the telegraph lines up and down to London’ (2007: 7). Elleke Boehmer similarly 'swivels' the 'conventional axis of interaction laterally'; the "“contact zone” of cultural and political exchange conventionally located between the European colonial centre and its periphery [is] instead ... positioned between peripheries' (2002: 2). Forming part of this intellectual turn are articulations of the Indian Ocean as an 'interregional arena' that was not wholly tamed into a 'British lake' during the nineteenth century (Bose 2006). Anticipated by scholarship produced by Jeffreys during and after her transoceanic correspondence, cultural theorists and historians are beginning to pay particular attention to South Africa's presence and functioning in this arena (Hofmeyr 2007).

The strand in this scholarship to which this article is most indebted is that which engages the idea of an Indian Ocean public sphere. Print culture emerges as a significant site through which to view the formation of various publics across the modern Indian Ocean arena. Indian Ocean port city journals and periodicals, notes Isabel Hofmeyr (2008: 22) 'frequently used cuttings from each other and so created a quoting circle that enacted the idea of an Indian Ocean public sphere.' Following the pioneering work of Mark Frost on South and Southeast Asia, ${ }^{3}$ Hofmeyr (2008: 12-13) introduces a set of critical questions: 'The south/south traffic of books and newspapers matched the

\footnotetext{
${ }^{3}$ Frost notes of colonial port cities in South and Southeast Asia during 1870-1920 that 'the traffic in knowledge and information of this type [newspapers, pamphlets, books and letters] was as heavily between the colonial settlements as it was between each individual settlement and Britain, and this was facilitated by the rapid extension of imperial mail services and the emergence of regional and international news syndicates' (2002: 940).
} 
equivalent traffic on a north/south axis. What were these books and pamphlets? What kinds of publics did they convene on their oceanic circuits?' This article takes up such enquiries as it explores a minor yet telling transoceanic exchange in the early twentieth century.

The historical context of the exchange- - which though slowing to a trickle through the late 1930s and 1940s continues until Sastri's death in Madras in 1946-is as revealing as its geographical reach. It is launched in the aftermath of African-Indian 'imperial connections' between 1860 and 1920 analysed by Metcalf, or the period 1890 to 1920 discussed by Boehmer, and the 'information explosion' in South and Southeast Asian port cities between 1870 and 1920 elaborated by Frost (2002: 940). End-stopped at 1920, these studies all raise the question of what follows in the wake of the imbrications and circulations they theorise. The 'continuous correspondence' between Jeffreys, Sastri and Rao offers something of a window into this period-providing a vantage point, in particular, onto the unfinished business of pre-1920 universalisms in the midst of emergent nationalisms taking concrete form on either side of the Indian Ocean. In the immediate aftermath of the exchange, otherwise antithetical nationalisms - the Indian postcolony and apartheid South Africa - were established that defined precisely the kinds of divisions against which Sastri, Rao and Jeffreys pitted themselves - the partition of the subcontinent and the internal segregation of South Africa—and which ruptured the transoceanic connections woven in a prior era.

Preceding and during the exchange in question, alternative imaginings of (trans)national polities had taken shape across the body of water separating India from South Africa. An inclusive Indian national identity (embracing Muslims) was informed by the experiences of Indians overseas (Metcalf 2007: 3) and particularly in South Africa, where M. K. Gandhi's sojourn had a profound impact on the national consciousness he would import back to India while Gandhi, in turn, 'brought the plight of the Indian overseas to the notice of Indian national opinion' (Tinker 1976: 23). The termination of indentured labour across the British Empire after 1920, argues Metcalf, 'led to a rapid waning of interest [in India] in the plight of the overseas Indian' (2007: 214), with the subcontinent increasingly turning inward, preoccupied with territorial nationalism. Sastri was the exception here, embodying an era progressively under erasure as he 'endeavored to keep India’s attention focused at least on the conditions of Indians in 
South Africa' (Metcalf 2007: 214). Maintaining the Moderate call for self-government within Empire during the era of nationalism, Sastri was an increasingly anachronistic figure. Representing India at the 1921 Round Table Conference in London, he opened proceedings by stating that 'To us, the Empire stands for equality, for absolute justice,' and sought assurance that all 'be entitled to move freely in any part of the Empire' (quoted in Tinker 1976: 47). Hugh Tinker suggests it was precisely this sense of being woven into the web of Empire with its promises of 'imperial citizenship' that kept overseas Indians visible on the Moderate agenda, while Extremists were increasingly preoccupied with events unfolding on Indian soil. For the Moderates, in contrast, the North-South axis of rule enables rather than stands in counterpoint to South-South axes of (af)filiation and circulation.

\section{Subjects of a trans-oceanic exchange: Sastri, Jeffreys and Rao}

Born in Valangaiman, Tamil Nadu on 22 September 1869, Sastri was an impassioned educator before meeting Gopāl Krishna Gokhale in 1906. Following this encounter, he sought admission in 1907 to the Servants of India Society that Gokhale had founded and assumed leadership therein after Gokhale's death in 1915. Three years later, conflict surrounding the Montagu-Chelmsford Reform proposals saw Sastri and the Servants of India Society seceding from the Indian National Congress and joining the Conference of the Moderates. Although they were later located in almost antagonistic political camps, Sastri nurtured a close relationship with Gandhi, who proposed him as first Agent of the Colonial Government of India in South Africa, an office created following the Round Table Conference of 1927 at which the 'Cape Town Agreement' was reached and to which Sastri was delegated as India’s representative.

The Agent was tasked with building bridges between white and Indian communities and between South Africa and India itself. As he expressed his mission on arrival in Durban in 1927: 'A new era is dawning on the relations between South Africa and India' (qtd. Jagadisan 1969: 91). Its first incumbent, Sastri set the tone for the Agency’s modus operandi, which Uma Mesthrie, whose doctoral thesis continues to offer the only detailed engagement with the Agency, elaborates: 'The Indian representatives were determined to influence white public opinion to accept the Indians within their midst. Based on the premise that ignorance bred misunderstanding and hostility, they 
undertook public lectures to educate white public opinion on Indian culture and civilization’ (Mesthrie 1987: 309).

Sastri's successes were eagerly reported in the Indian print media, particularly in The Servant of India newsletter, the fortnightly organ of the organisation he led. His South African lectures, the newsletter enthused, 'drew record audiences' across the country (29 Nov. 1928: 629). Gandhi’s Young India, calling on both Indian and South African publics to support his mission in 'Sastri as First Ambassador' (Young India, 28 April 1927) and 'Appeal to South African Indians' (Young India, 19 May 1927), also keenly followed his South Africa itinerary. In 'Sastri’s work' (Young India, 18 Oct. 1928), Gandhi notes approvingly:

He has been delivering to large and select audiences of Europeans lectures on Indian philosophy and culture which have stirred European imagination and softened the hard crust of prejudice which has hitherto prevented the general body of Europeans from seeing anything good in the Indian. These lectures are perhaps his greatest and most permanent contribution to the Indian cause in South Africa. (880)

Writing to G. A. Natesan from the RMS Windsor Castle, en route to Durban on 18 November 1928, following what he describes as 'a strenuous campaign in Cape Town,' Sastri observes with satisfaction that his lectures had 'created an appreciation of Indian philosophy and literature’ (in Jagadisan 1963: 178). Included in the legacy of his tenure in South Africa was Sastri College, opened in Durban soon after his departure, and 130 volumes on Indian philosophy, literature and history that, reports The Servant of India (13 December 1928), he donated to the Durban Library Group before his return to India.

By far the most significant legacy of Sastri’s cultural ambassadorship was his perceived bridge-building between members of the divided South African polity and between South Africa and India. The South African Indian Congress delegation to New Delhi issued on his death a tribute recognising him as one who 'brought us closer to India and knit the bonds of love, affection and attachment between us and India' (The Hindu, 20 April 1946; rpt. Sastriana 3 [1964]: 2). ${ }^{4}$ Unpublished but stored among Sastri’s papers in the Nehru Memorial Museum and Library, New Delhi, is a letter from the Port

\footnotetext{
${ }^{4}$ They elaborate: 'There are two sons of India whose names will shine as beacon lights to us in the dark continent of South Africa [--] a white South Africa whose whole philosophy of life is to oppress and suppress non-Europeans. One is Mahatma Gandhi and the other is Mr. Sastri, who has gone' (2; emphasis in the original).
} 
Elizabeth branch of the Cape Native Voter's Association regretting Sastri's 'impending departure from this land' and hailing him as the 'champion' of not only '[his] people' but 'of the darker races of the British Empire and in particular those of the Bantu people in South Africa': 'When you leave the shores of this country we desire you to feel that the native inhabitants of this land treasure the warmest feelings for yourself and sincere sympathies for your fellow Indians in this land. May we hope that you will ever sustain the bond that has been created between our people and yours.'

White South Africa was particularly effusive in its accolades. The Natal Advertiser declared Sastri 'without question, the greatest man in South Africa; the ablest orator, the shrewdest diplomat, and, withal, the most accomplished interpreter of one civilisation to another that we have ever had in our midst.' With an evocative turn of phrase, they conclude: 'Mr Sastri has, by his personal genius, shattered the bulkheads that keep East and West in the Union in separate compartments' (rpt. in 'Tributes Paid to the Late Srinivasa Sastri by the South African Press,' Sastriana 5 [1966]: 9-10).

One of Sastri's most adoring white South African converts was Jeffreys, whose later intellectual trajectory was both enabled and informed by her subsequent epistolary exchange with him and his loyal personal secretary. Jeffreys would emerge out of this 'continuous correspondence' as an amateur scholar prolifically penning the history of Cape Town and confronting the solidifying divisions of pre- and early apartheid South Africa with its past entanglements in the Indian Ocean arena. ${ }^{5}$ Under the nom-de-plume 'Hamsi,' given her by Sastri, ${ }^{6}$ Jeffreys also published poems in the South African print media that enumerated and entwined what she declared to be her 'threefold heritage' at the tip of Africa and the cusp of Atlantic and Indian Ocean trade routes. Before publication in the Cape Town dailies, and later in two volumes-Summer Rain (1931) and Sea-Foam (1934) — these poems themselves traveled across the space they sought to bridge: many were folded into the weighty missives Jeffreys would dispatch in time for

\footnotetext{
${ }^{5}$ On Jeffreys's oeuvre, see Samuelson (2007, 2009, 2010 and 2011).

${ }^{6}$ As she records in an autobiographical reflection written c. 1953: "YYour name is Hamsi," he said. "In Hindu mythology Hamsi the swan has the power to drink of milk \& water mixed, and to take only the milk and leave the water. The meaning is that Hamsi the swan can discriminate between the good \& evil in men's hearts, and take only the good.”' 'The Love Story of Little Marie,' Jeffreys Collection, A1567, vol. 38, Western Cape Archives and Repository Service. It is notable that Sastri is here apparently echoing Gandhi's riposte to Katherine Mayo in an article in Young India (15 Sept. 1927: 349) that concludes: 'Everything created by God, animate or inanimate, has its good and bad side. The wise man, like the fabled bird which separating the cream of milk from its waters helps himself to the cream leaving the water alone, will take the good from everything leaving the bad alone.'
} 
each 'India mail'; others were smuggled on board the SS Karoa to comprise Sastri's 'ship mail' on his return voyage to India in 1929. Both volumes employ as governing tropes the turbulent ocean joining yet separating India and Africa—anticipating by a couple of years Rabindranath Tagore’s ‘Africa' (1938), with its imagery of an 'angry sea' casting asunder Africa and the South Asian subcontinent. Sea-Foam, published in the wake of Jeffreys's visit to India in 1932, opens with a poem titled 'The Ship' in which the vessel of transport becomes an emblem of self, 'forever sailing alone in midocean.' As 'Hamsi,' Jeffreys also contributed to the convening of a transoceanic public by writing articles on current South African affairs for The Servant of India.

Rao’s two-year stint in South Africa, followed by his 'continuous correspondence' with Jeffreys, had an equally profound effect on his later interventions. Taking up the reigns of editor of The Servant of India newsletter from S. G. Vaze soon after his return from South Africa, Rao penned numerous pamphlets and books on the segregation of Indians in South Africa and efforts to stem the flow of Indians to South Africa; national integration in India and the potential role of the English language in producing national unity and warding off 'another major partition in India' (c.1961: 46); the imbrications of East and West and what he termed, in his dedication to Cultural Conflicts: Cause and Cure, 'the Unity of Civilisation'; and, advancing their political legacy in independent India, Gokhale and Sastri. In addition to print-media, Rao also circulated his version of nation-premised on and struck through by transnational affiliations and exchangesvia radio, with a series of talks delivered over All India Radio, Bangalore, and published retrospectively as Foreign Friends of India's Freedom.

\section{Circulating texts in a 'continuous correspondence': A transoceanic archive}

The 'continuous correspondence’ to which Rao refers in his letter of 14 May 1931 begins one evening in 1928, after Jeffreys had attended a lecture by Sastri in Cape Town. As she would later recall,

\footnotetext{
English was my greatest love. It was, therefore, with intense caginess that I went to hear this man, who according to all accounts, spoke more beautifully than anyone had ever heard before. I felt this could not possibly be true: I was mistaken ... Never before or since have I heard such eloquence, such beauty of diction, such choice of words. It was bewildering, looking at his dark face, beneath a simply folded muslin turban, to realize that he had received all his education in India. $^{7}$
}

\footnotetext{
7 'Sublime experience' (unpublished), Jeffreys Collection, A1567, vol. 38, Western Cape Archives and Records Service.
} 
'Bewildered' by what she perceives as the contradictory signs of 'beauty of diction' and Sastri’s ‘dark face,' Jeffreys is set adrift from her anchor of Anglophilia. Immediately after the lecture, she addresses to Sastri the first missive in this correspondence, which would end up being published by Gandhi in Young India where, framed by Gandhi's editorial foreword, it was presented as 'evidence of the way in which Sjt. Sastri has stolen into the hearts of many South Africans.' 'The work of silent conversation will be a far greater help to our people in South Africa than any amount of official concession,' Gandhi observes, elaborating: 'The conversation makes even these possible.'

Young India had fallen under Gandhi’s editorial hand following his ‘apprenticeship as a journalist' (Dhupelia-Mesthrie 2003) with Indian Opinion in South Africa. ${ }^{9}$ As Hofmeyr says of Indian Opinion, so too of Young India: it functioned 'as a clearinghouse, gathering messages from different part of the world and presenting them to the reader who can see all the destinations from which they have come.' In the process, periodicals such as Indian Opinion and Young India carved out 'particular pathways of circulation' (Hofmeyr 2008: 17) and produced various (trans)national publics. As he explains in his autobiography, Gandhi used Young India and its vernacular sister publication Navajivan to 'educat[e] the reading public in Satygraha'; the two journals, he concludes, 'enabled me freely to ventilate my views' (Gandhi 2007 [1927-29]: 426).

Re-presented to a reading public out of which Gandhi was forging 'India' by 'ventilating [his] views' in print across the nation-under-construction and along a circulation network spooling out across the Indian Ocean, Jeffreys's letter enthused that Sastri’s lecture had opened up to her the vistas of a heritage long shrouded from her regard: 'You have opened for us the magic casements of the East, and every lover of good things among us will find the distant peaks calling, calling, calling, as they are calling me, with ... an insistence which must be obeyed.' Hailed by this East now unveiled before her eyes, Jeffreys opens up her bounded self, recognising her previously disavowed South Asian ancestry: '[The] message you brought belongs to me, it is a heritage buried beneath two hundred years of white blood and Western civilisation. For I, too, have been of the East, and have something of the East in me. Two hundred years

\footnotetext{
8 ‘Another Tribute,' Young India, 7 Feb. 1929: 47.

${ }^{9}$ On the publishing history of Indian Opinion, see also Hofmeyr (2008: 11-15).
} 
ago white men brought as slave to this country a girl of Jaffnapatnam. ${ }^{10}$ This epistolary utterance comprises a complex moment in white South Africa. To contemporary eyes, the self-indulgence of the claim to South Asian slave ancestry from within an oppressive white polity is striking. However, the personal and political significance of the recognition cannot be downplayed.

Unwittingly entering this acknowledgement into public print culture that was circulating within and beyond India in the form of a private letter that articulates a radical unmooring of self, Jeffreys draws on it again 30 years later in her major public intervention against a white South Africa repressing its oceanic entanglements. In the last instalment of a series in the iconic South African magazine Drum that explored 'Where Do Coloureds Come From?' and 'How White are the Whites?,' Jeffreys would bravely declare her South Asian ancestry in an apartheid South Africa founded on constructions of racial purity. Equally significant is Jeffreys's attention to $17^{\text {th }}$ century flows taking place under the banner of the Dutch East India Company as part of her answer to the titular questions of the series: these flows have been repressed on both sides of the ocean (see Dhupelia-Mesthrie 2007), and were notably submerged during the 2010 celebrations marking 150 years of Indian presence in South Africa, which index as the beginning of Indian history in South Africa the arrival on 16 November 1860 of the first ship bearing indentured labourers. Jeffreys's longer historical vision, informed as it may be by personal gratification, creates a platform for engaging relations between South Africa and South Asia in more extended and nuanced ways. Most significantly, it draws 'India' into the scene of Cape creolisation, rather than holding it apart as the homeland of Durban's diasporic community.

The subject of the lecture Sastri delivered in Cape Town to Jeffreys's appreciative ears was the legend Śakuntalā and its literary travels and translations across the centuries and seas. ${ }^{11}$ The speech itself does not appear to have been recorded, though a report in Indian Opinion on the same lecture delivered in Johannesburg reveals that in it Sastri articulated a liberal humanist understanding of literature as a medium in and through

\footnotetext{
10 'Another Tribute,' Young India, 7 Feb. 1929: 47; original letter located in V. S. Sastri Private Papers, Nehru Memorial Museum and Library, New Delhi.

${ }^{11}$ For a detailed study of the textual history of Śakuntalā, from its origins in the Mahābhārata via Kālidāsa to its rearticulations in German romanticism and middle-class Indian nationalism, see Thapar (1999).
} 
which to knit the fractures fostered by the colonial state. ${ }^{12}$ Jeffreys's second epistle highlights the ways in which this lecture established for her a sense of common ground, restoring what she had previously experienced as a fragmented world literature:

Goethe's poem on the Sakuntala I knew and loved many years ago. And before you quoted from the charming English translation I stood there in the aisle, trying to fit together the lovely phrases, which were lying in my mind in scattered fragments. I cannot tell you of the double joy of linking the old sweetness with a new and lovelier song. ${ }^{13}$

Sastri's act of gathering together a text dispersed across divided national and linguistic communities, while translating it back from its northern circulations to its southern genesis, is received by Jeffreys as one in which the construction of a world literature is tied to the project of bridging cultural and political differences.

This was indeed the task that Sastri assigned himself as Agent whereas, for Jeffreys, the resonance between a fractured universal textual culture and her own sense of having (been) cast off (from) her South Asian ancestry is acute. Resonant imagery appears in her letter a year later: 'I am a tiny chip that was taken off the base of a beautiful vase,' she tells Sastri; 'I only want to be joined on again where I belong. ${ }^{\text {, }}$ Jeffreys writes later that Sastri's gift to her was 'pride and acceptance in [her] twofold heritage,'15 which enabled her to produce a braided self out of the divided skeins of her own history, and which in later years was extended into a 'threefold heritage, 16 that drew 'Africa' into her weave of subjectivity (see Samuelson 2007, 2011). Set in motion by this epistolary exchange (to recall her self-construction as a ship 'forever sailing alone in mid-ocean'), she was able to reconstruct her fractured heritage, 'fit[ting] together' the ocean currents and continental location comprising her subjectivity.

The reorientation set in motion by Sastri’s lecture was enhanced by the intense reading programme on India on which Jeffreys embarked. Within a year of the lecture, she reports having devoured 'about 30 really good books on India,' concluding: 'I am

\footnotetext{
${ }^{12}$ Indian Opinion, 19 Oct. 1928; my thanks to Isabel Hofmeyr for finding this report.

${ }^{13}$ Letter from Jeffreys to Sastri, 28 Nov. 1928, V. S. Sastri Private Papers, Nehru Memorial Museum and Library.

${ }^{14}$ Letters from M.K. Jeffreys to V.S.S. Sastri and P. Kodanda Rao, Jeffreys Collection, A1657, vol.12, Western Cape Archives and Records Service. Unless otherwise indicated, all further quotations of letters by Jeffreys are from this source.

15 ‘Sublime Experience’ (unpublished autobiographical fragment), Jeffreys Collection, A1567, vol. 36, Western Cape Archives and Records Service.

16 'Colour: A Threefold Heritage' (unpublished poem), Jeffreys Collection, A1567, vol. 38, Western Cape Archives and Records Service.
} 
developing tremendous respect for Ghandi [sic], whom I referred to in tones of the deepest contempt and detestation only last year. It is, with me, a time of growth.' Each subsequent missive reports on a book completed or in progress, from accounts by retired Raj administrators to 'racy and entertaining' tales.

Initially dependent on a North-South axis feeding studies of the subcontinent into the Cape Town library system, Jeffreys’ ‘continuous correspondence’ with Rao enabled her to establish a South-South axis of textual circulation. Writing from Mombasa in March 1929, Rao queried whether Jeffreys had read 'Miss Mayo’s book,' urging her, 'If you can get a copy,' to ‘please read “Unhappy India” by Lajpat Rai.’ Katherine Mayo’s Mother India, dismissed by Gandhi in Young India (15 Sept. 1927) as a ‘drain inspector's report' (339-49), was an international sensation at the time: not only does The Servant of India host numerous rebuttals from within India, but it also includes furious responses from the author of the regular feature 'Our South African Letter.' Writing to his brother from Cape Town in February 1928, Sastri observes: 'Everyone is asking about Mother India' (in Jagadisan 1963: 172). Mother India, Jeffreys surmises, was not only informing North-South relations, but was equally shaping and souring those between Indian and white South Africans. She bemoans to Sastri: 'My mother has been reading her or someone kindred \& warning me about you \& your people! ${ }^{17}$ As the South Africa correspondent of The Servant of India points out: 'South Africa was never overflowing with sympathy for, and understanding of, India and Miss Mayo's book has not tended to improve the situation. Her book seems to have a great vogue in this country. A number of its reviews and notes have appeared in all kinds of papers' (5 April 1928: 193).

Whereas studies such as Mother India were widely available in South African libraries (to judge from the list of titles Jeffreys was able to access), Lajpat Rai's rebuttal of Mayo was certainly not. Rao eagerly supplemented their holdings with a regular book parcel from India. Early in their correspondence he asks: 'Did you read Sister Nivedita (Miss Margaret Noble), her book, "Web of Indian Life”? Please do. Published by Longmans, I believe.' Evidently unable to source a copy in South Africa, Jeffreys had one dispatched to her by Rao. In exchange, he exacted a stream of news-cuttings

\footnotetext{
${ }^{17}$ See Samuelson (2010) for a discussion of Jeffreys's keen sense of having to negotiate the spectre of Mayo’s caustic gaze when posing as an ‘authority’ on India.
} 
addressing Indian South African affairs and reporting on developments in African politics. Among other titles, he requested copies of the proceedings of the 1929 BantuEuropean Conference in Cape Town and of Eddie Roux’s communist newsletter Umsebenzi. At the same time, Jeffreys used the personal letter form to keep Rao abreast of the South African reception of events unfolding in India, which grew more avid following Sastri’s term as Agent.

After subscribing to The Servant of India, Jeffreys was able to manage her own reading programme, drawing into her orbit the texts circulating in its advertising pages. In May 1930 she ordered 'a life of Gokhale,' followed later that year by C. F. Andrews’s biography, Mahatma Gandhi: His Own Story. In the pages of The Servant of India, too, she would have seen reflected across the Indian Ocean the face of the increasingly troubled South African polity.

Launched in February 1918, with its first issues edited by Sastri, The Servant of India collected news from across the subcontinent and presented it under regional headings, advancing as 'imagined community' a heterodox and textured polity. International coverage in its inaugural issue was restricted to the European war-effort, but through the advertising pages that would later prove so useful to Jeffreys it opened up to South Africa in its second instalment, offering for purchase Gandhi's Speeches and Writing and signalling the inclusion therein of the essay 'The South African Indian Question.' The third issue, published 7 March 1918, marked the emergence of what would soon become a pattern: the inclusion of short news features on South African affairs (in this case, the threatened imposition of new railway regulations that would restrict and prohibit non-European mobility in South Africa). That South Africa should henceforth feature regularly in its pages is not really remarkable. Before the close association forged between South Africa and the Servants of India during and following Sastri's term as Agent, Gokhale had in 1912 travelled there to bring the plight of overseas Indians to attention in the subcontinent. As is the case in the exchange explored in this article, personal connections and the circulation of subjects inform and shape textual circulation and political solidarity. ${ }^{18}$

\footnotetext{
${ }^{18}$ Not explored in this article, though forming part of the larger research from which it is drawn, is the role played by affect, the intimate and the personal, in shaping political positions; see Samuelson (2008); see also L. Gandhi (2006) on 'affective communities,' an exploration somewhat anticipated by Rao (1973).
} 
In the period I surveyed during the 'continuous correspondence' (1927-1932), South Africa is an almost constant topic in The Servant of India. The Cape Town Agreement of 1927 is heatedly discussed, while the physical movement of the first Indian Agent across the ocean is mirrored in coverage of his speeches, from his delivery in Poona before his departure on 10 March 1927 to his lecture on the 'Indian Problem in South Africa,' presented on arrival in Pretoria on 28 July 1927. During Sastri’s tenure as Agent, the newsletter carried in each fortnightly instalment stories tracing his every move, applauding each success and circulating across India excerpts or summaries of the speeches with which he was countering the anti-Indian sentiment of white South Africa. The Servant of India produces around the textual subject in motion of Sastri what Hofmeyr, writing of the South African Indian Opinion, describes as an 'Indian Ocean travelogue' (2008: 18). At the same time, stressing the simultaneity of concerns and reading publics on each side of the Indian Ocean, it interpolates a transoceanic ‘imagined community’ (Anderson 1983). It explicitly envisages and evokes such a community when, for instance, it urges the 'speedy withdrawal of the objectionable section' of the South African Liquor Bill that would compromise Indian employment in the hospitality industry 'before an agitation on both sides of the Indian Ocean thickens and kills with the frost of recrimination and denunciation the tender sapling of friendship that is being nursed between the two nations' (The Servant of India, Nov. 1927: 513).

Jeffreys also contributed to the convening of this transoceanic public. At Rao's urging, she published in the newsletter in 1930 an article titled 'Women's Franchise and the Native in South Africa' in which she deplores the ways in which white women's enfranchisement was used to disenfranchise Africans at the Cape. Having positioned herself as a node in a transoceanic textual network, she is able to draw trenchant comparisons between women in India and women in South Africa. Indeed, her interest in women's suffrage in South Africa appears to have been honed, if not sparked, by 'the interesting pamphlets about the All India Woman's Conference' that Rao dispatched to her earlier that year.

Literary texts and analyses joined the flow of news media, political pamphlets, biographies and philosophical treatises. Initially, Rudyard Kipling's Kim sounded the terms of Jeffreys's engagement; as she proclaimed of the novel to Rao, 'It seems to have 
been in my blood, part of my being, as long as I can recall.' Kim spoke in complex and contradictory ways to Jeffreys's newfound subjectivity, which cracked open the brittle shell of whiteness by recognising what she refers to as 'the treasures of my blood.' Early in the exchange, Jeffreys appears to have received Kim in similar ways to Ashis Nandy, who finds the novel to be Kipling's 'once-in-a-lifetime break with his painfullyconstituted imperial self ... [,] baring his latent awareness’ of his 'biculturality’ (1998 [1994]: 44-45).

However, Kipling ultimately proves of limited value to Jeffreys; with his antipathy towards Eurasians, he certainly did not enable her later pioneering efforts to represent the apartheid-nation as a 'miscege-nation.' Through her transoceanic affiliations, Jeffreys would be increasingly aligned with the position articulated by Edward Said that sees Kim’s loyalties falling firmly on the side of Empire (Said 1994: 148). At the same time, this 'overwhelmingly male novel' (Said 1994: 136) excluded Jeffreys as gendered subject from the public she was both convening and attempting to enter.

Turning from Kipling, Jeffreys found new orientations in the writings of Rabindranath Tagore, to which she was introduced by Rao. In 1929, Rao’s precious copy of Tagore’s play, Chitra (first published in Bengali in 1914), was dispatched across the ocean by mail boat. By late 1930, Jeffreys had herself secured his novel, Gora (first published in Bengali in 1909 and rendered into English in 1924). Tacking back and forth between the two, she forged an alternative textual subjectivity to that proffered by Kim. Gora, which takes up Kim's production of a hybrid colonial subject without foreclosing its possibilities, proved particularly suggestive. Whereas the journey in Kim is from a championing of syncreticism to a retreat into purity, in Gora this trajectory is reversed: Kim's shape-shifting subjectivity ultimately settles into a duplicit yet stable performance as undercover agent, while Gora's initially narrow nationalism is opened up. In contrast to Kim, Gora moreover sweeps aside 'blood' in favour of advancing affilial relations, precipitating for Jeffreys a shift from tracing genealogies to elaborating cultural entanglements.

In October 1930, Jeffreys informed Sastri that she could barely tear herself away from Tagore's novel in order to pen her letter: 'I might as well say I have met those people; known them intimately for years ... I do not know when I have so much enjoyed a book or felt so unbearably aggravated by the vagaries of the people in it, or loved them with 
such affectionate understanding,' she concludes. She identifies most keenly with the novel's eponymous hero in his journey from a dogmatic quest for a pure and untouched India towards an acknowledgement of his own alterity and celebration of the fissured texture of the India he discovers.

Thus, an apparent movement from a North-South to a South-South textual axis marks a significant shift in Jeffreys's attempts to theorise self and society in and from South Africa. It is notable, though, that rather than turning from its imperial predecessor, Gora stages an extended intertextual dialogue with Kim, which is signalled in the most striking plot similarity: both eponymous heroes are the orphaned offspring of Irish parents. Yet, while both journey across India on the Grand Trunk Road, each follows this imperial infrastructure towards distinct ends. For Kim, it is the path along which to inscribe the colony into the imperial panopticon; for Gora, it opens up a terrain for imaginings of nation as unbounded but sovereign entity.

The North-South axis is revealed to be as productive as it is oppressive-enabling resistant responses to the structures it advances. Exemplary here is Tagore's response to Kipling: taking up and resisting Kipling's imperial vision by re-enacting his plot, Tagore produces imaginings of India that refuse the retreat into antithetical autochthonous positions - a refusal that is in turn represented in the novel's plot. A similar point attends the infrastructure introduced to advance the Northern imperial mission in the South: the web of telegraph cables, mail-boats and passenger liners that enmesh the colonised South are teased out to provide threads of South-South connectivity.

Just as great was the impact on Jeffreys of Chitra, which instead of writing back to colonial fictions is, like Śakuntalā, adapted from the Mahābhārata-a source that Sastri has encoded for Jeffreys as the matrix of a universal culture. During an extended literary-critical exchange, Chitra provided the platform on which Jeffreys and Rao thrashed out perceived differences and points of connection between East and West regarding, in particular, the aesthetics and ethics of love and service and the roles available to women within these positions. Initially finding the play irrevocably foreign, Jeffreys was seduced by the hospitality it extends to women in the public sphere, shifting her allegiance from what the Nobel Prize committee would celebrate as Kipling’s ‘virile’ structures. In the gender-bending forms 
suggested in Chitra and the trans-cultural movements of Gora, Jeffreys ultimately found an idiom with which to articulate the ways in which transoceanic affiliations were reorienting her white South African subjectivity: 'I shall exchange one of my head veils for one of your turbans when I see you-isn’t that the right way to become brothers?' she asks Rao. ${ }^{19}$

\section{Conclusion}

Inheriting from the late imperial era explored by Boehmer, Frost and Metcalf a web of ideological and physical infrastructure that sets textual subjects in motion across the Indian Ocean arena, the correspondents in this exchange tack back and forth between imperial citizenship and anti-colonial positions, establishing in the interstices of the North-South axis pockets of South-South affiliation. Historically located in a nationbuilding era, they continue to convene transoceanic communities in order to conceptualise events unfolding on either side of the Indian Ocean and to advance national communities characterised by permeability and fluidity.

In the wake of her transoceanic exchange, Jeffreys spent the remainder of her life exploring the political and social implications of South Africa's geo-historical location at the tip of Africa and at the meeting point of Indian and Atlantic trade routes in order to generate new (trans)national imaginings. In and through immersion in a transoceanic public, Jeffreys undertook pioneering research that presented her Cape context and South African society in ways that are now, post-apartheid and in a new global order, re-surfacing. Her conceptions of Cape history and national culture, in particular, anticipate and enrich historian Kerry Ward's evocative and influential casting of Jeffreys’s city of residence as the ‘Cape cauldron’ (Ward 2009) and the resonant concept of 'entanglement' that cultural studies theorist Sarah Nuttall (2009) puts forward in order to approach a South Africa previously analysed through the rubric of separation. Surfacing the 'entangled' histories and cultural forms of the 'Cape cauldron' and percolating them through a stratified South Africa, Jeffreys presents ways of thinking India in South Africa that exceed the bounds maintained in diasporic studies,

\footnotetext{
${ }^{19}$ In the play inspiring Jeffreys's rhetoric here, Chitra, a woman raised as a son, exhorts the gods to make her 'superbly beautiful' for a year, in order to secure the heart of the celibate, Arjuna. Having achieved her aim, she shuns her 'borrowed beauty,' claiming that her 'body has become [her] own rival' (163). Yet she fears that if she stood true in her unwomanly guise, Arjuna would reject her. Unveiling into her masculine attire, she is however embraced by him.
} 
while weaving along with her Moderate Indian interlocutors South-South connections out of filaments of the North-South imperial web.

Jeffreys’s six-part series titled 'Where Do Coloureds Come From?' and 'How White are the Whites?,' published in Drum during 1959 to 1960, reveals most keenly the impact of this flow of letters as she traces the oceanic currents feeding into and producing as entangled web a South Africa nation founded on separatism. The series was explicitly aimed at producing an inclusive national community by ridding South Africans of their 'colour complex, ${ }^{20}$ and was described by Drum's editor of the time as having 'caused more lively controversy than any series published in South Africa during the past ten years. ${ }^{21}$ Entering print culture in this forum, and republished in the Beat of Drum retrospective of 1984, Jeffreys’s pioneering research was presented to two generations of South Africans living under the ideological stranglehold of apartheid. As a consequence of being published in Drum, which played a crucial role in '(re)producing trans-national and pan-African interconnectedness' (Odhiambo 2006: 160), it was set in motion once more, entering new 'pathways of circulation' across the continent.

The research disseminated along these circuits, and that produced by Rao in postindependence India, drew the threads of a South-South affiliation woven out of the North-South axis across the mid-century nationalist rupture, creating a transoceanic archive that in itself undoes the constitutive divisions of mid-century nation-states. ${ }^{22}$ In their production of this archive, both establish Tagore as touchstone, and suggest ways of reading textual culture that do not divide national traditions but rather approach South Africa through Tagore. Here they anticipate a recent address by Benin's ambassador to UNESCO, Olabiyi Babalola Joseph Yaï (2008), who stages a transoceanic address through a reading of Tagore's 'Africa,' which inscribes an oceanic rupture separating the (sub)continents of Africa and South Asia, in order to animate his vision of a 'new universalism.' Yaï expresses the hope that this 'new universalism' will be determined by the previously colonised world, particularly Africa and India, but does not seek to restrict it to the South or to centre the South in a new global order; rather, he

\footnotetext{
20 'Where Do Coloureds Come From?,' Drum, August 1959: 48.

${ }^{21}$ Quoted in 'How White Are the Whites? What I learned about My Own Ancestry,' Drum, February 1960, 26.

${ }^{22}$ I am broadly indebted to Uma Dhupelia-Mesthrie for this point, which elaborates her comment that transoceanic archival research helps to undo apartheid-style divided histories.
} 
positions the South as weaving the 'nest' in which 'the world meets.' Elaborating an idiom and ontology of the bridge while 'shattering the bulkheads' between India and South Africa, the participants in this 'continuous correspondence' establish an imaginative geography to underpin this 'new universalism' that our present is reaching toward.

\section{Reference List}

Anderson, B. 1983, Imagined Communities: Reflections on the Origin and Spread of Nationalism. Verso, London.

Boehmer, E. 2002, Empire, the National, and the Postcolonial, 1890-1920. Oxford University Press, Oxford.

Bose, S. 2006, A Hundred Horizons: The Indian Ocean in the Age of Global Empire. Harvard University Press, Cambridge, Mass.

Dhupelia-Mesthrie, U. 2003, 'The Significance of Indian Opinion.' Address to Conference on the Alternative Media to Commemorate the Centenary of the Founding of Indian Opinion, 4 June, Durban. Online, available: http://www.sahistory.org.za/pages/artsmediaculture/arts/media/indian-opinion.htm (Accessed 25 January 2009). 2007, 'The Place of India in South African History: Academic Scholarship, Past, Present and Future,' South African Historical Journal, vol. 57: 12-34.

Frost, M. 2002, “"Wider Opportunities”: Religious Revival, Nationalist Awakening and the Global Dimension in Colombo, 1870-1920,' Modern Asian Studies, vol. 36, no. 4: 937-67.

Gandhi, Leela 2006, Affective Communities: Anti-Colonial Thought, Fin-de-Siècle Radicalism, and the Politics of Friendship. Duke University Press, Durham, NC.

Gandhi, Mahatma (M.K.) 1935 [1927-1928], Young India 1927-1928. S. Ganesan, Madras. 2007 [1927-1929], The Story of My Experiments with Truth: An Autobiography. Trans. M. Desai. Penguin, London.

Jagadisan, J.N., (ed.) 1963 [1944], Letters of the Right Honourable V.S. Srinivasa Sastri. Asia Publishing House, Bombay. 1969, V.S. Srinivasa Sastri. Builders of Modern India, Ministry of Information and Broadcasting, Government of India, Nasik.

Jeffreys, M.K. 1931, Summer Rain: The Songs of Hamsi. Cape Town: Citadel Press. 1934, Sea-Foam: The Songs of Hamsi. Cape Town: Nasionale Pers.

Hofmeyr, I. 2007, 'The Black Atlantic Meets the Indian Ocean: Forging New Paradigms of Transnationalism for the Global South-Literary and Cultural Perspectives,' Social Dynamics, vol. 33, no. 2: 1-32. 2008, 'Indian Ocean Lives and Letters,' English in Africa, vol. 35, no. 1: 9-23.

'How White Are the Whites? What I learned about My Own Ancestry' 1960, Drum, February. Kipling, R. 1965 [1901], Kim. Macmillan, London.

Mesthrie, U. S. 1987, From Sastri to Deshmukh: A Study of the Role of the Government of India's Representatives in South Africa, 1927 to 1946. Unpublished PhD. thesis, Dept. of History, University of Natal.

Metcalf, T.R. 2007, Imperial Connections: India in the Indian Ocean Arena, 1860-1920. University of California Press, Berkeley.

Nandy, A. 1998 [1994], The Illegitimacy of Nationalism: Rabindranath Tagore and the Politics of Self. Oxford University Press, New Delhi.

'Nobel Prize in Literature Winners, 2008-1901,' No date. Nobel Prize Internet Archive. Online, available: http://almaz.com/nobel/literature (Accessed 25 January 2009).

Nuttall, S. 2009, Entanglement: Literary and Cultural Reflections on Post-apartheid. Wits University Press, Johannesburg.

Odhiambo, T. 2006, 'Inventing Africa in the $20^{\text {th }}$ Century: Cultural Imagination and Transnationalism in Drum Magazine,’ African Studies, vol. 65, no. 2: 157-74.

Rao, P.K. 1939, East versus West: A Denial of Contrast. Allen \& Unwin, London. 1946, Cultural Conflicts: Cause and Cure. Padmaja Publications, Baroda. c.1961, The Question of National Integration. Institute of Politics and Social Studies, Calcutta. 
1963, The Right Honourable V.S. Srinivasa Sastri: A Political Biography. Asia Publishing House, New York.

1973, Foreign Friends of India's Freedom. PTI Book Company, Bangalore/Madras.

Said, E.W. 1994, Culture and Imperialism. Vintage, New York.

Samuelson, M. 2007, 'Re-imagining South Africa via a Passage to India: M.K. Jeffreys' Archive of the Indian Ocean World,' Social Dynamics, vol. 33, no. 2: 61-85.

2008, 'A Community of Letters on the Indian Ocean Rim: Friendship, Fraternity and (Af)filial Love,' English in Africa, vol. 31, no. 5: 27-43.

2010, 'Oceanic Charades: The Female Figures of M. K. Jeffreys’s Passage to India,’ in Eyes Across the Water: Navigating the Indian Ocean, (eds) I. Hofmeyr, P. Gupta \& M. Pearson, Unisa Press, Pretoria, 258-270.

2011 'Orienting the Cape: A “White” Woman Writing Islam in South Africa,' Social Dynamics, vol. 37, no. 3: 363-78.

Tagore, R. n.d. [1909], Gora. Translator unknown (1924). N.p.: Kessinger’s Rare Reprints. 1962 [1914], 'Chitra,' in Collected Poems and Plays of Rabindranath Tagore. Macmillan, London, 149-73. 1993 [1938], ‘Africa,’ in Selected Poems, (ed.) William Radice, Penguin, London, 102-3.

Thapar, R. 1999, Śakuntalā: Texts, Readings, Histories. Kali for Women, New Delhi.

Tincker, H. 1976, Separate and Unequal: India and the Indians in the British Commonwealth. Vikas Publishing House, Delhi.

Ward, K. 2009, Networks of Empire: Forced Migration in the Dutch East India Company. Cambridge University Press, Cambridge.

'Where Do Coloureds Come From?' 1959, Drum, August.

Yaï, O.B.J. 2008, ‘Africa, African Diaspora and the Prospect of Global Cultural Exchange,' lecture presented at India International Centre in Delhi, Mainstream vol. 46, no. 47. Online, available: http://www.mainstreamweekly.net/article1031.html (Accessed 3 January 2011). 